\title{
Concentration and periods of application of prohexadione calcium in the growth of strawberry seedlings
}

\section{Concentrações e épocas de aplicação do proexadione cálcio no crescimento de mudas de morangueiro}

\author{
Caroline Farias Barreto ${ }^{1 *}$; Leticia Vanni Ferreira ${ }^{2}$; Savana Irribarem Costa ${ }^{1}$; \\ Andressa Vighi Schiavon ${ }^{3}$; Tais Barbosa Becker ${ }^{1}$; Gerson Kleinick Vignolo²; Luis \\ Eduardo Correa Antunes ${ }^{4}$
}

\begin{abstract}
For strawberry cultivation in Brazil, producers are dependent on imported seedlings. An alternative strategy to reduce this dependence is the use of seedlings obtained from nursery plants grown in a protected environment. However, as these seedlings are produced in the summer and planted at the end of this season or the spring of the following year, it is necessary to control growth to reduce the energy costs of the plants. The objective of this study was to evaluate the effect of different concentrations and periods of application of proexadione calcium (ProCa) on growth control of strawberry seedlings. The experiment was carried out in a greenhouse with seedlings of the cultivars 'Aromas' and 'Camarosa', produced by rooting stolons and kept in polystyrene trays of 72 cells in a substrate of carbonized rice husk. The experimental design was completely randomized, with a $4 \times 2$ factorial scheme (4 concentrations of ProCa: 0, 100, 200, and $400 \mathrm{mg} \mathrm{L}^{-1} \times 2$ periods of application: at 20 and 30 days after the planting period of rooting stolon). Plant survival, crown diameter, petiole length, total leaf area, specific leaf area, chlorophyll concentration, and dry mass of the crown and shoot were evaluated. The application of ProCa at 20 days after the planting period of the rooting stolon at the concentrations of 200 and $400 \mathrm{mg} \mathrm{L}^{-1}$ favored the reduction of petiole length in plants of 'Aromas' strawberry and total leaf aerial in 'Camarosa' strawberry. The application of ProCa from the concentration of $100 \mathrm{mg} \mathrm{L}^{-1}$ reduced the vegetative growth of 'Aromas' and 'Camarosa' strawberry seedlings cultivated in substrate. Key-words: Fragaria $\times$ ananassa. Inhibitor of gibberellin. Plant regulators.
\end{abstract}

\section{Resumo}

Para o cultivo do morangueiro no Brasil existe a dependência dos produtores em utilizar mudas importadas. Com intuito de reduzir essa dependência, uma das alternativas é o uso de mudas obtidas de plantas matrizes cultivadas em ambiente protegido. Porém, como essas mudas são produzidas no verão e plantadas no final desta estação ou no outono do ano seguinte, é necessário controlar o crescimento para diminuir os gastos energéticos das plantas. Objetivou-se com o trabalho avaliar o efeito de diferentes concentrações e épocas de aplicação de proexadione cálcio (ProCa) no controle de

\footnotetext{
${ }^{1}$ Discentes de Doutorado em Agronomia, Universidade Federal de Pelotas, UFPel, Pelotas, RS, Brasil. E-mail: carol_fariasb@ hotmail.com; vana_irribarem@hotmail.com; taisbarbosabecker@hotmail.com

2 Drs. em Agronomia, RS, Brasil. E-mail: letivf@hotmail.com; gerson_vignolo@yahoo.com.br

3 Discente de Mestrado em Agronomia, Universidade Federal de Pelotas, UFPel, Pelotas, RS, Brasil. E-mail: andressa.vighi@ gmail.com

4 Pesquisador, Embrapa Clima Temperado, EMBRAPA, Pelotas, RS, Brasil. E-mail: luis.antunes@embrapa.br

* Author for correspondence
} 
crescimento de mudas de morangueiro com torrão. $\mathrm{O}$ experimento foi realizado em casa de vegetação com mudas das cultivares Aromas e Camarosa, produzidas por enraizamento de estolões e mantidas em bandejas de poliestireno de 72 células em substrato casca de arroz carbonizada. $\mathrm{O}$ delineamento experimental utilizado foi inteiramente casualizado, com esquema fatorial 4x2 (4 concentrações de ProCa: 0, 100, 200 e $400 \mathrm{mg} \mathrm{L}^{-1}$ x 2 épocas de aplicação: aos 20 e aos 30 dias após o período de plantio do estolão para enraizamento). Avaliaram-se nas mudas: sobrevivência de plantas, diâmetro de coroa, comprimento de pecíolo, área foliar total, área foliar específica, concentração de clorofila e massa seca da coroa e da parte aérea. A aplicação de ProCa aos 20 dias após o período de plantio do estolão para enraizamento nas concentrações de 200 e $400 \mathrm{mg} \mathrm{L}^{-1}$ favorece a redução do comprimento do pecíolo em morangueiro 'Aromas' e a aérea foliar total em morangueiro 'Camarosa'. A aplicação de ProCa a partir da concentração de $100 \mathrm{mg} \mathrm{L}^{-1}$ reduz o crescimento vegetativo de mudas de morangueiro 'Aromas' e 'Camarosa' cultivadas em substrato.

Palavras-chave: Fragaria x ananassa. Inibidor de giberelina. Reguladores vegetais.

\section{Introduction}

Strawberry cultivation plays an important socioeconomic role in South and Southeast Brazil, with production destined for in natura consumption and for the food industry (MAZARO et al., 2013). In spite of this potential, the culture presents some limiting factors, particularly in obtaining seedlings, because the greatest part of the seedlings used in Brazil are imported from Patagonia (Argentina and Chile), due to the excellent conditions for cultivation in that region (ANTUNES; PERES, 2013; GONÇALVES et al., 2016). In addition to the growing dependence of producers on imported seedlings, the planting time of the crops needs to be matched to the time of arrival of the seedlings, as there are constant delays in their delivery (DAL PICIO et al., 2013), which causes difficulties in planning and conducting cultivation.

The production of seedlings in Brazil thus stands in need of strategies to reduce the dependence of producers on imported seedlings. One alternative proposed is the use of seedlings obtained from mother plants grown in protected environments during spring and summer (MENZEL; SMITH, 2012). This type of seedling has advantages, including the possibility of staggering production and planting seedlings at the recommended time in other words, anticipating the planting, which allows early production with greater profitability $(\mathrm{COCCO}$ et al., 2011).
However, while seedling production initiatives in the national territory have been undertaken in the summer, the seedlings were planted only at the end of the season or the following spring. During this period, excessive development of the aerial part occurs, which necessitates control of plant growth (PEREIRA et al., 2016). These seedlings, when produced under favorable environmental conditions, may also accumulate fewer reserves in the crown and roots, which consequently decreases the quality of the seedling (COCCO et al., 2015).

One of the alternatives to reduce vegetative growth of fruit is the use of growth regulators (HAWERROTH; PETRI, 2014; REZAZADEH; HARKESS, 2015; PASA; EINHORNET, 2017). The growth regulators used in fruit cultivation include prohexadione-calcium (ProCa) (calcium 3-oxide-4-propionyl-5-oxo-3-cyclohexane carboxylate), which is a phytoregulator that inhibits the final steps of gibberellin (GA) biosynthesis (HAWERROTH; PETRI, 2014). ProCa reduces the activity of $\mathrm{GA}_{20} 3 \beta$-hydroxylase, an enzyme that acts on the conversion of $\mathrm{GA}_{20}$ (inactive gibberellins) to $\mathrm{GA}_{1}$ (active gibberellins), thus controlling vegetative growth (KANG et al., 2010; HAWERROTH; PETRI, 2014). ProCa is effective in controlling vegetative growth and thus can be used for this purpose in strawberry seedlings (REEKIE et al., 2005; PEREIRA et al., 2016), as the domestic seedlings exhibit greater leaf growth and reduced reserve accumulation. 
In this context, in order to reduce the dependence of Brazilian producers on the acquisition of imported strawberry seedlings, studies should be carried out to improve the quality of the domestic seedlings. However, for this it is necessary to control the growth of the aerial part of these seedlings to accumulate more reserves in the crown and root and, thus, develop seedlings of better quality. Therefore, the objective of this study was to evaluate the effect of different concentrations and times of application of ProCa on the growth control of strawberry seedlings.

\section{Material and Methods}

The experiment was carried out in a greenhouse at the EMBRAPA Temperate Climate Research Center, located in the municipality of Pelotas, Rio Grande do Sul (latitude: $31^{\circ} 40^{\prime} \mathrm{S}$ and longitude: $52^{\circ} 26^{\prime} \mathrm{W}$, altitude $60 \mathrm{~m}$ ) during the months of March to May 2017. The strawberry cultivars 'Camarosa' (short day) and 'Aromas' (neutral day) were used. These seedlings were produced by rooting stolons removed from parent plants that were planted in November 2016 and maintained on roof tiles covered with black and white double-sided polyethylene. The culture channels were filled with carbonized rice husk. Stolons were set to rooting in March 2017 in 72 cell polystyrene trays with Carolina Soil Padrão ${ }^{\circledR}$ substrate.

The seedlings were kept for 10 days in a nebulization chamber with an irrigation frequency of 10 seconds every 30 minutes for the initial period of rooting. Afterwards, the seedlings were transferred to the acclimatization chamber, where they were kept for 20 days, under controlled irrigation (during the development period), with an irrigation frequency of thirty seconds, four times a day and a flow rate of $30 \mathrm{~L}$ per hour. After the end of the development period, the seedlings were submitted to the growth control treatments, with the application of the plant growth regulator ProCa (Viviful ${ }^{\circledR}$ with $27.5 \%$ i.a.). The application of the product was carried out via hand spray (1 liter capacity), using a volume of 3 $\mathrm{mL}$ per plant.

The experimental design was completely randomized, with a $4 \times 2$ factorial scheme (4 concentrations of prohexadione calcium: 0, 100, 200, and $400 \mathrm{mg} \mathrm{L}^{-1} \times 2$ periods of application: at 20 and 30 days after the planting period of rooting stolon) with 4 replicates, each replicate composed of 12 plants. At 60 days after the beginning of the development period, the following evaluations were performed: plant survival, obtained by counting the number of live plants; crown diameter $(\mathrm{mm})$, measured with the aid of a digital caliper; petiole length $(\mathrm{cm})$, made using a graduated ruler; total leaf area $\left(\mathrm{cm}^{2}\right.$ plant $\left.{ }^{-1}\right)$, measured using the LI-3100C Area Meter equipment (Li-Cor Inc., Lincoln, NE, USA); specific leaf area, obtained by the relation between total leaf area and number of leaves; concentration of chlorophyll $a, b$ and total, evaluated with a chlorophyll meter (ClorofiLOG - Falker Automação Agrícola Ltda., Porto Alegre, RS); and dry mass of the crown $(\mathrm{g})$ and aerial part $(\mathrm{g})$, obtained by drying the different parts of all the seedlings in an oven at $65{ }^{\circ} \mathrm{C}$ until constant weight.

The data were submitted to analysis of variance by the F-test and, when the effect was significant, the Tukey's test was performed and the variables with a significant effect for the quantitative factor were submitted to polynomial regression analysis using the statistical software ASSISTAT (SILVA; AZEVEDO, 2016).

\section{Results and Discussion}

The petiole length of 'Aromas' strawberry seedlings cultivated on substrate showed an interaction between ProCa concentrations and periods of application (Figure 1A). It was observed that the petiole length of the seedlings of this cultivar decreased with increasing ProCa concentrations at both periods of application. 
Figure 1. Petiole length (A), total leaf area (B), aerial part dry mass (C), chlorophyll $a$ (D), chlorophyll $b$ (E), and total chlorophyll (F) in response to application of concentrations and period of application of calcium prohexadione in 'Aromas' strawberry seedlings cultivated in substrate. Embrapa Climate Temperate, RS, 2017.
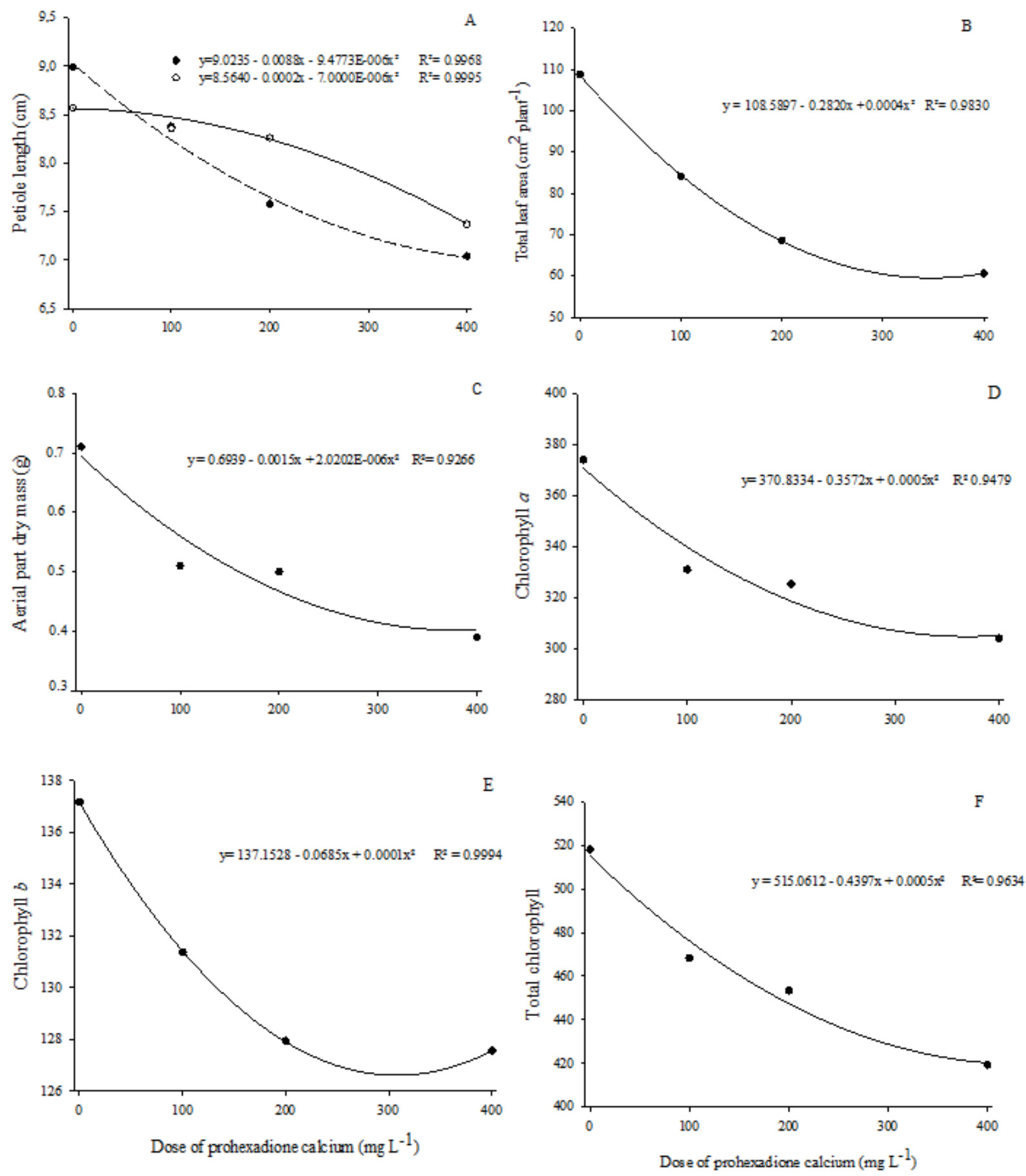

Regarding the periods of application, the reduction in petiole length was greater when ProCa was applied at 20 days after the planting period of the rooting stolon under the application of 200

and $400 \mathrm{mg} \mathrm{L}^{-1}$. his effect is probably due to ProCa acting in the inhibition of gibberellin synthesis. This reduces the levels of gibberellin, which functions in cell division, cell elongation, and growth (TAIZ 
et al., 2017). Reduction in the length of apple (HAWERROTH; PETRI, 2014) and pear (PASA; EINHORNET, 2014, PASA; EINHORNET, 2017) branches has also been observed, as well as reduction of the petiole of strawberry seedlings (PEREIRA et al., 2016) following the application of ProCa.

The concentration of ProCa had a significant effect on total leaf area, aerial part dry matter, and chlorophyll $a, b$, and total content. However, none of these variables presented differences between the periods of application of ProCa in the strawberry cultivar 'Aromas'. The total leaf area of 'Aromas' strawberry seedlings was influenced by ProCa concentrations and the lowest values were observed with the applications of 200 and $400 \mathrm{mg} \mathrm{L}^{-1}$, which decreased leaf area by $36.9 \%$ and $44.2 \%$ respectively in relation to the $0 \mathrm{mg} \mathrm{L}^{-1}$ dose of ProCa (Figure 1B). In this way, the effect of reducing the leaf area of the seedlings caused by the ProCa concentrations may be due to the reduction of leaf size.

Similarly to the total leaf area, the dry mass of the aerial part of the 'Aromas' strawberry seedlings decreased with increased ProCa concentrations (Figure 1C). The greatest reduction was observed with the application of $400 \mathrm{mg} \mathrm{L}^{-1}$ of ProCa, which decreased the aerial part dry mass by $45.07 \%$ in relation to the control seedlings. This reduction of the leaf aerial parts observed in the seedlings with ProCa application, and especially in the highest concentration tested in this experiment $\left(400 \mathrm{mg} \mathrm{L}^{-1}\right)$, possibly occurred due to the hormonal regulation exerted by ProCa. That is, when this phytoregulator is applied, it induces a reduction of GA levels that inhibits cell elongation and leaf growth (PEREIRA et al., 2016).

Chlorophyll $a$ (Figure 1D), chlorophyll $b$ (Figure 1E), and total chlorophyll (Figure 1F) content decreased with increasing concentrations of ProCa. Thus, ProCa in this experiment altered the concentration of pigments involved in photosynthesis, since chlorophyll $a$ is the pigment used to carry out the photochemical phase of photosynthesis and chlorophyll $b$, together with other pigments, aids in the absorption of light and the transfer of radiant energy to the reaction centers (TAIZ et al., 2017). In addition to the effect of ProCa on chlorophyll content, Pereira et al. (2016) verified that the use of this phytoregulator also causes physiological changes in strawberry seedlings, since it changes the photosynthetic activity of the leaves.

The percentage of survival, crown diameter, crown dry mass, and specific leaf area in 'Aromas' strawberry seedlings grown on substrate were not influenced by ProCa concentrations or period of application. According to Privé et al. (2006), response to the use of ProCa depends on the seasonal pattern of aerial part growth, which is influenced by cultivar, plant management, and environmental factors.

In this study, average survival values of $96.34 \%$, average crown diameter of $8.96 \mathrm{~mm}$, crown dry mass of $0.23 \mathrm{~g}$, and specific leaf area of 18.29 were found in 'Aromas' strawberry seedlings submitted to the application of ProCa. Although ProCa reduces the aerial part of the strawberry seedlings, this phytorregulator did not reduce the crown diameter or the crown dry mass, which are important parameters for evaluation of seedling quality, since they are positively correlated with productive potential (COCCO et al. al., 2015).

In the cultivar 'Camarosa', there were interactions between concentrations and period of application of ProCa for the variable total leaf area (Figure 2A). The more ProCa the plants received, the lower the values of total leaf area in both periods of application. However, the greatest reduction occurred when the ProCa was applied at 30 days after the planting period of the rooting stolon. Reductions in the total leaf area of $39.06,45.86$, and $51.45 \%$ concentrations of ProCa of 100, 200, and $400 \mathrm{mg} \mathrm{L}^{-1}$ respectively, when compared to the plants that did not receive the phytoregulator. 
Figure 2. Total leaf area (A), specific leaf area (B), aerial part dry mass (C), petiole length (D), crown diameter (E), and crown dry mass $(\mathrm{F})$ in response to the application of prohexadione calcium concentrations in 'Camarosa' strawberry seedlings cultivated in substrate. Embrapa Temperate Climate, RS, 2017.
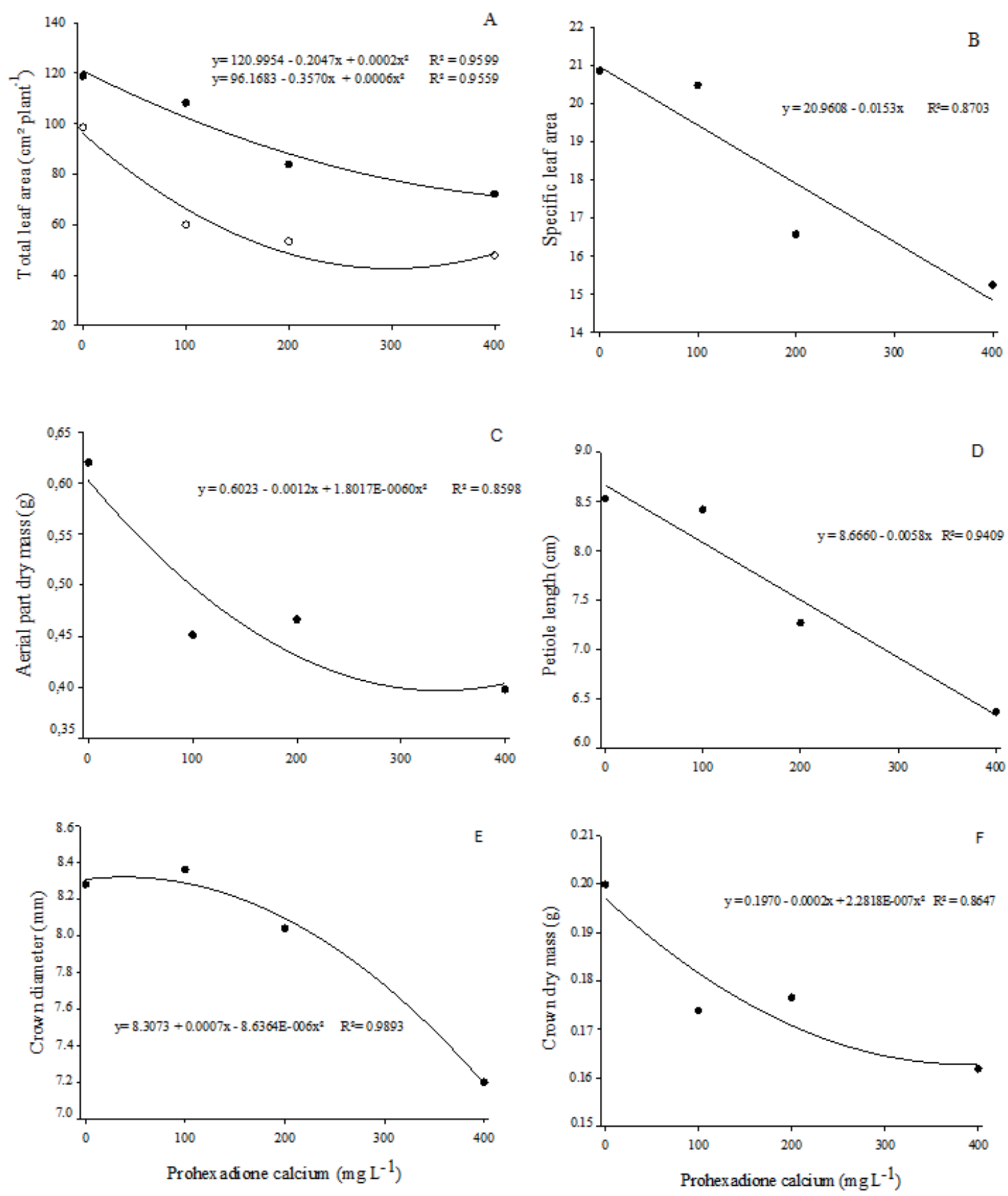

When ProCa was applied at 20 days after the planting period of the rooting stolon of 'Camarosa' strawberry seedlings, the greatest reductions in the total leaf area occurred in plants that received 200 and $400 \mathrm{mg} \mathrm{L}^{-1}$ ProCa, which were $29.42 \%$ and $39.23 \%$, respectively, when compared to

the controls seedlings. Pereira et al. (2016) also observed a reduction of $32 \%, 26 \%$, and $17 \%$ in the total leaf area in the 'Camarosa' strawberry seedlings, in response to ProCa 200, 400, and 800 $\mathrm{mg} \mathrm{L}^{-1}$ concentrations respectively, when applied at 20 days after the planting period of rooting stolon. 
The variables specific leaf area, aerial part dry mass, petiole length, crown diameter, and crown dry mass in the 'Camarosa' strawberry seedlings were influenced by ProCa concentrations. Specific leaf area of seedlings, which is the relationship between total leaf area and number of leaves, decreased linearly with increasing ProCa concentration and the smallest specific leaf area was observed in the 'Camarosa' seedlings that received $400 \mathrm{mg} \mathrm{L}^{-1}$ of ProCa (Figure 2B).

The increase in ProCa concentration reduced the aerial part dry mass of the 'Camarosa' strawberry seedlings (Figure 2C). Regardless of the tested concentration, the dry mass of the aerial part of the strawberry seedlings that received the phytorregulator was considerably lower than that of the seedlings that did not.

The petiole length of the 'Camarosa' strawberry seedlings was reduced following the application of ProCa (Figure 2D). The concentration of $400 \mathrm{mg}$ $\mathrm{L}^{-1}$ of ProCa provided the smallest value of petiole length in the seedlings, with an average of $6.37 \mathrm{~cm}$ and a reduction of $25.05 \%$ in relation to the control treatment. Similar responses were found by Pereira et al. (2016), who obtained a reduction of 24 and $58 \%$ in the petiole length of 'Camarosa' strawberry seedlings with the application of 200 and $400 \mathrm{mg} \mathrm{L}^{-1}$ of ProCa, respectively.

The crown diameter (Figure 2E) and crown dry mass (Figure 2F) decreased with increasing ProCa concentration. In both variables, the reduction was greater when the $400 \mathrm{mg} \mathrm{L}^{-1}$ ProCa concentration was used. At this concentration, the crown diameter presented an average value of $7.2 \mathrm{~mm}$, which was lower than that found in bare rooted seedlings, in which the diameter of the crown should be greater than $8 \mathrm{~mm}$ (COCCO et al., 2011). However, for seedlings produced in substrate, as is the case of this study, we do not yet have a recommendation of adequate diameter.

The period of application of ProCa in 'Camarosa' strawberry seedlings affected the crown diameter and amount of chlorophyll $a$ and total leaf area. Both variables had the highest values when the application was made at 20 days after the planting period of rooting stolon. In this study, average values of 8.53 $\mathrm{mm}$ for crown diameter, 362.1 for chlorophyll $a$ content, and 501.84 for total chlorophyll content were observed following the application of ProCa at 20 days after the planting period of the rooting stolon of the seedlings of the cultivar 'Camarosa'.

The different ProCa concentrations did not influence the survival percentage of 'Camarosa' strawberry seedlings, nor did the chlorophyll $a$, $b$, or total content in the leaves. For this cultivar, the average survival values of the seedlings were $80.72 \%$, after application of ProCa. The chlorophyll $a, b$, and total content in 'Camarosa' strawberry leaves submitted to ProCa application at 100, 200, and $400 \mathrm{mg} \mathrm{L}^{-1}$ presented average values of 343.46 , 139.61, and 473.51, respectively.

In both cultivars in this study, the application of ProCa did not cause statistical differences for the percentage of survival of the seedlings, indicating that the concentrations and the periods of application of ProCa had no phytotoxic effect. This result corroborates with those of Pereira et al. (2016), in which the application of ProCa in 'Camarosa' strawberry seedlings at concentrations of $0,25,50$, $100,200,400$, and $800 \mathrm{mg} \mathrm{L}^{-1}$ had no effect on plant mortality.

Concentrations from $100 \mathrm{mg} \mathrm{L}^{-1}$ of ProCa reduce the vegetative growth of 'Camarosa' and 'Aromas' strawberry seedlings, mainly the leaf area. The concentrations of 200 and $400 \mathrm{mg} \mathrm{L}^{-1}$ of ProCa reduced the vegetative growth of the seedlings more markedly. However, this greater reduction of the leaf area may have an effect in reducing the photosynthetic rate, which may interfere with the development of this change in the field. In this sense, it is necessary to perform further studies that must be carried out after transplanting the seedlings to the field to investigate the possible impacts on aspects of production and fruit quality. 


\section{Conclusion}

The application of prohexadione calcium at concentrations from $100 \mathrm{mg} \mathrm{L}^{-1}$ reduces the vegetative growth of 'Aromas' and 'Camarosa' strawberry seedlings grown on substrate.

The period of application of ProCa influences the petiole length in plants of 'Aromas' strawberry and in the total leaf area in 'Camarosa' strawberry.

\section{References}

ANTUNES, L. E. C.; PERES, N. A. Strawberry production in Brazil and South America. International Journal of Fruit Science, New York, v. 13, n. 1-2, p. 156161, 2013.

COCCO, C.; ANDRIOLO, J. L.; CARDOSO, F. L.; ERPEN, L.; SCHMITT, O. J. Crown size and transplant type on the strawberry yield. Scientia Agricola, Piracicaba, v. 68, n. 4, p. 489-493, 2011.

COCCO, C.; GONÇALVES, M. A.; PICOLOTTO, L.; FERREIRA, L. V.; ANTUNES, L. E. C. Crescimento, desenvolvimento e produção de morangueiro a partir de mudas com diferentes volumes de torrão. Revista Brasileira de Fruticultura, Jaboticabal, v. 34, n. 4, p. 919-927, 2015.

DAL PICIO, M.; ANDRIOLO, J. L.; JÄNISCH, D. I. SCHMITT, O. J; LERNER, M. A. Fruit yield of strawberry stock plants after runner tip production by different cultivars. Horticultura Brasileira, Vitória da Conquista, v. 31, n. 3, p. 375-379, 2013.

GONÇALVES, M. A.; COCCO, C.; VIGNOLO, G. K.; PICOLOTTO, L.; ANTUNES, L. E. C. Comportamento produtivo de cultivares de morangueiro estabelecidos a partir de mudas com Torrão. Revista Eletrônica Científica da UERGS, Porto Alegre, v. 2, n. 3, p. 277-283, 2016.

HAWERROTH, F. J.; PETRI, J. L. Crescimento vegetativo de macieiras 'Fuji suprema' sob influência da época de aplicação de proexadione cálcio. Revista Brasileira de Fruticultura, Jaboticabal, v. 36, n. 2, p. 373-380, 2014.

KANG, S. M.; KIM, J. T.; HAMAYUN, M.; HWANG, I. C.; KHAN, A. L.; KIM, Y. H.; LEE, J. H.; LEE, I. J. Influence of prohexadione-calcium on growth and gibberellins content of Chinese cabbage grown in alpine region of South Korea. Scientia Horticulturae, Amsterdam, v. 125, n. 2, p. 88-92, 2010.
MAZARO, S. M.; MANGNABOSCO, M. C.; CAPRINI, M.; CITADIN, I.; PAULUS, D.; GOUVEA, A. Produção e qualidade de morangueiro sob diferentes concentrações de calda bordalesa, sulfocálcica e biofertilizante supermagro. Semina: Ciências Agrárias, Londrina, v. 34, n. 6, p. 3285-3294, 2013. Suplemento 1.

MENZEL, C. M.; SMITH, L. Effect of time of planting and plant size on the productivity of 'Festival' and 'Florida Fortuna' strawberry plants in a subtropical environment. HortTechnology, Alexandria, v. 22, n. 3, p. 330-337, 2012.

PASA, M. S.; EINHORN, T. C. Heading cuts and prohexadione-calcium affect the growth and development of 'd'Anjou' pear shoots in a high-density orchard. Scientia Horticulturae, Amsterdam, v. 168, n. 2, p. $267-$ 271, 2014.

PASA, M. S.; EINHORN, T. C. Prohexadione calcium on shoot growth of 'Starkrimson' pear trees. Pesquisa Agropecuária Brasileira, Brasília, v. 52, n. 2, p. 75-83, 2017.

PEREIRA, I. S.; GONÇALVES, M. A.; PICOLOTTO, L.; VIGNOLO, G. K.; ANTUNES, L. E. C. Controle do crescimento de mudas de morangueiro 'Camarosa' cultivadas em substrato comercial pela aplicação de proexadione cálcio. Revista de Ciências Agrárias/ Amazonian Journal of Agricultural and Environmental Sciences, Belém, v. 59, n. 1, p. 93-98, 2016.

PRIVÉ, J. P.; CLINE, J.; FAVA, A. Influence of prohexadione calcium (Apogee ${ }^{\circledR}$ ) on shoot growth of non-bearing mature apple trees in two different growing regions. Canadian Journal of Plant Science, Ottawa, v. 86, n. 1, p. 227-233, 2006.

REEKIE, J. Y.; HICKLENTON, P. R.; STRUIK, P. C. Prohexadione-calcium modifies growth and increases photosynthesis in strawberry nursery plants. Canadian Journal of Plant Science, Ottawa, v. 85, n. 3, p. 671-677, 2005.

REZAZADEH, A.; HARKESS, R. L. Effects of pinching, number of cuttings per pot, and plant growth regulators on height control of purple firespike. Hort Technology, Alexandria, v. 25, n. 3, p. 71-75, 2015.

SILVA, F. de A. S.; AZEVEDO, C. A. V. de. The Assistat Software Version 7.7 and its use in the analysis of experimental data. African Journal of Agricultural Research, v. 11, n. 39, p. 3733-3740, 2016.

TAIZ, L.; ZEIGER, E.; MOLLER, I. M.; MURPHY, A. Fisiologia e desenvolvimento vegetal. 6. ed. Porto Alegre: Artmed, 2017. 858 p. 